\title{
"Your Kung Fu is very good, Master Fiore!" Asian and European fight books in comparison
}

\author{
Sixt Wetzler \\ Deutsches Klingenmuseum Solingen \\ s.wetzler@solingen.de
}

\begin{abstract}
The phenomenon of the fight book is not restricted to the European tradition. Similar artefacts, usually combining text and image to describe the techniques of close quarter combat with and without weapons, exist also in various Asian cultures, in China, Japan, Korea, and India. In the article, the question shall be raised in how far and to which end fight books of different cultures can be taken into one perspective, and be compared. To do so, similarities and dissimilarities between European and early Chinese fight books will be pointed out, and preliminary areas for comparison will be introduced. The aim of the article is to raise awareness for the topic, and to lay the ground for further discussion between specialists on the respective European and Chinese fields.

Keywords: fight books, martial arts studies, Chinese martial arts, comparative approach, Qi Jiguang.
\end{abstract}

\section{THE COMPARATIVE APPROACH IN MARTIAL ARTS STUDIES}

As the readers of this journal will know, academic research into the written sources of medieval and early modern European martial arts, and most of all into the fight books, has been a prosperous field in the last years. The articles of the Acta Periodica Duellatorum itself testify to this; a most recent pinnacle of the development is the publication of the volume "Late Medieval and Early Modern Fight Books", edited by Daniel Jaquet et al..$^{1}$ At the same time, research in and topics related to the historical European martial arts have been presented in a wider framework, namely within the emerging field of martial arts studies. ${ }^{2}$ Already the first German conference on "Kampfkunst and Kampfsport" (held in April 2011 at the University of Bayreuth), ${ }^{3}$ and

\footnotetext{
1 Jaquet et al., Fight Books.

${ }^{2}$ For an introduction to martial arts studies, see Bowman, Martial Arts Studies.

3 Conference volume: Kuhn et al., Kampfleunst und Kampfsport. A result of the conference was the founding of the Kommission Kampfleunst und Kampfsport (commission for martial arts and combat
} 
also the first English-speaking conference dedicated to the topic (held in June 2015 at the University of Cardiff) ${ }^{4}$ featured lectures that either dealt with European phenomena exclusively, or drew on European material and integrated it into wider perspectives. The latter approach - the integration of HEMA research into the comparative study of martial arts as a global phenomenon - is one which promises to work in two directions, and to yield results on two levels: On the one hand, the vast amount of relevant European sources allow for a far more detailed and diverse understanding of the many possible Gestalten that martial can take in different social settings. On the other hand, phenomena from other parts of the world can serve as reference points, sharpening our perspectives on HEMA. This is not only true where the physical realities of combat are taken into account, such as body techniques, or weaponry. It is also true concerning more abstract classes of phenomena, such as media representation, teaching methodology, myths and philosophy, social structure, or the connection to the wider cultural context. ${ }^{5}$

One of these classes of phenomena shall be in the focus of the article at hand - namely, the fight books of the Chinese martial arts tradition, and in which regards they can and should be compared to their European counterparts.

A comparison of two independent entities is not without problems. The first problem is a methodological one: On which basis does the researcher assume that the phenomena he or she wants to compare do at all belong to the same category? In his article on "comparison as a method and constitutive approach in religious studies", German historian of religion Oliver Freiberger discussed this difficulty:

Asking where such pre-knowledge comes from, we will get back to associative and subjective constructions [...] In most cases, the religious tradition that a researcher knows best will give the frame of reference $[. .$.$] The danger is to look for something in another religion$ that, even if it exists there, has a completely different meaning, position, or relevance. ${ }^{6}$

sports) in the Deutsche Vereinigung für Sportwissenschaft (German Association for Sports Science), see http://www.sportwissenschaft.de/index.php?id=kkk, accessed 27.09.2016.

4 For a conference program, see https://mastudiesrn.wordpress.com/conference-2/, accessed 27.09.2016.

5 Wetzler, 'Martial Arts Studies', pp. 27-28.

6 "Geht man nun der Frage nach, woher dieses Vorwissen eigentlich stammt, landet man letztlich wieder bei assoziativ-subjektiven Konstruktionen [...] Meist bildet diejenige religiöse Tradition, die den Forschern am besten vertraut ist, den Bezugsrahmen [...] Es besteht die Gefahr, dass man in anderen Religionen nach etwas sucht, das dort - selbst wenn man es findet - eine ganz andere Bedeutung, Stellung oder Relevanz besitzt.” Freiberger, 'Vergleich', p. 206. 
Freiberger's arguments can be equally applied, mutatis mutandis, to martial arts studies. He admits that subjective pre-categories are inevitable, but nevertheless underlines the potentials of a thorough comparison. Consequently, he seeks to refine the intuitive first impulse of any comparison into a well-reflected process:

The starting point for a comparative study can be a definition of terms (as wide and open as possible) to isolate the topics of the study; and a result of the comparison will be a modification and precision of the terms. These more precise terms can then be the basis for a further comparative study [which] will prevent the essentialisation of terms. ${ }^{7}$

As this quote indicates, to Freiberger, the aim of a comparative study is not to "show the identity of different phenomena - thus defining their postulated 'true core' - but instead [...] to analyse similarities and analogies regarding a certain aspect. In regards to a different aspect, the phenomena may well be different." ${ }^{\text {N }}$ Not the "inner essence", but the meaning of a phenomenon in its cultural and historical context is what shall be revealed.

This should be born in mind when comparing martial arts of different times and places with each other. An often-heard functionalistic oversimplification of the development and constant transformation of martial arts seeks to explain their Gestalt in evolutionist terms: Because the aim of all martial arts, so this explanation goes, is the submission of a human opponent, and because humans have only two arms and two legs and are bound to the rules of biomechanics, all martial arts are the same at their "true core" - namely, a selection of effective and efficient combat manoeuvres. In this perspective, all incarnations of martial arts not directly related to the development of combative supremacy are later, superfluous adulterations. It is poorly fitted to adequately describe the heterogeneity of the various styles of martial arts. The empty hand methods of Fiore dei Liberi do not look like tanglang kung fu, which does not look like capeoira. And this not because one style understood the requirements of physical combat better than the other, but because they all fulfill(ed) certain functions within their cultural context, and were

\footnotetext{
7 "Der Ausgangspunkt einer Vergleichsstudie kann also eine (möglichst weite und offene) Definition der Begriffe sein, die den Gegenstandsbereich der Studie eingrenzen; und als Ergebnis des Vergleichs kann die Begrifflichkeit modifiziert und präzisiert werden. Die so präzisierten Begriffe können wiederum der Ausgangspunkt für eine weitere Vergleichsstudie sein, aufgrund derer die Definitionen wiederum modifiziert werden. Eine solche kontinuierliche gegenseitige Befruchtung von Begriffsbestimmung und Vergleich verhindert eine Essentialisierung von Begriffen und Vorstellungen.” Ibid., pp. 207-8.

8 “Identität von Phänomenen festzustellen - womit ihr postuliertes 'Wesen’ bestimmt würde sondern vielmehr [...] Ähnlichkeiten und Analogien von Erscheinungen im Hinblick auf einen bestimmten Aspekt zu untersuchen; im Hinblick auf andere Aspekte mögen sich die Erscheinungen durchaus unterscheiden.” Ibid., p. 210.
} 
shaped by a multitude of factors beyond immediate combative application. (See Eric Burkart's article in this volume for a further discussion of this matter.)

If we want to understand a given martial arts style, no matter whether recent or historic, we must strive to identify and understand the multiple factors that shaped it, and to analyse which roles it plays or played in its surrounding society. This endeavour can be greatly facilitated by a comparative approach.

The second problem for a comparison is a practical one: Often, a researcher will not be a specialist in all the areas from whence the objects derive he aims to compare. In my case, I am no Sinologist; unfortunately, I am not able to read the Chinese sources in the original language. Should this stop me from the undertaking of discussing any Chinese material in the first place? I do not think so. Prohibiting ourselves to think and write about topics we are not specialized in would ultimately mean to make new thought impossible. By its very design, martial arts studies are a discipline so heterogeneous and interdisciplinary that anyone engaging in it will necessarily have to trespass the boundaries of his accustomed field of research. However, what is necessary is the honest and critical reflection of one's own competence, and of the possible results of one's work. For the article at hand, that means I am not hoping to give definite answers on the matter. I am rather aiming to outline possible categories worth comparing, and thus to prepare the ground for a future discussion. This discussion has then to be carried on as a dialogue, between specialists for the individual fields.

\section{HISTORICAL EUROPEAN AND CHINESE MARTIAL ARTS}

If we accept the comparative approach as suitable method for martial arts studies, the next question would naturally be: What shall we compare? As mentioned by Freiberger, this question may at first be answered by a rather subjective, spontaneous impulse. In a second step, we should then ask if the phenomena we have taken into consideration are indeed suitable (and promising enough) for a comparative study.

As stated before, topic of this article is the fight book in different incarnations, in the historical European and the historical Chinese martial arts. The singular - "the fight book", not "fight books" - is chosen consciously here: To make our comparison possible in the first place, we shall assume a congruency huge enough to allow for this singular. Several factors seem to justify this assumption:

- Gestalt of the martial arts: Generally spoken, the martial arts styles of both pre-modern Europe and China are universal systems, teaching techniques not only for the use of various weapons, but also for empty hands combat. The weapons employed may be not identical, but are reasonably similar in dimensions and intended use. Staffs and halberds, long axes and two-handed swords from the one culture would have surely been 'understood' in the 
other without much confusion. ${ }^{9}$ And even a superficial look will provide many examples of (seemingly) similar body positions and stances (see Fig. 1 and 2). ${ }^{10}$

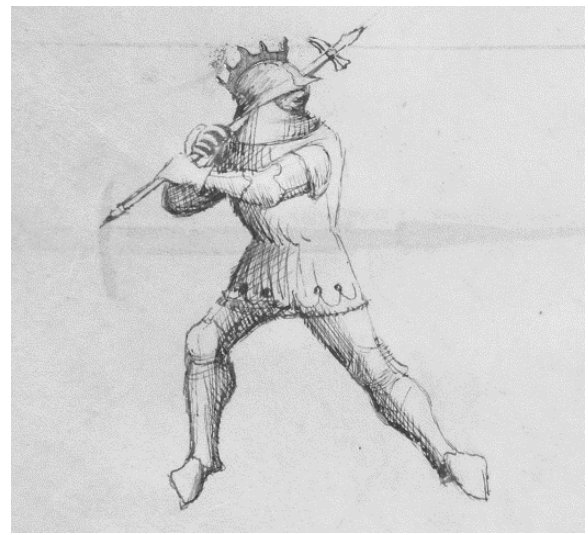

Figure 1: Posta de donna. Fiore dei Liberi, Il Fior di Battaglia, ca. 1410 (Los Angeles, J. Paul Getty Museum, MS Ludwig XV 13, fol. 35v). Digital image courtesy of the Getty's Open Content Program.

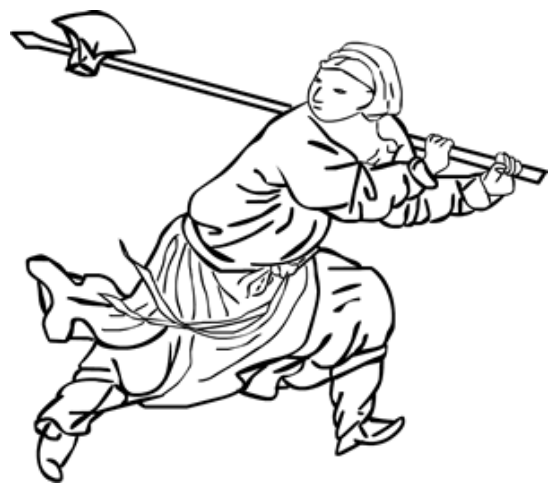

Figure 2: Position with the long shaft axe. Cheng Zi Yi, Long Shaft Axe, unknown date. Reproduced with permission of Jack Chen, wnw.chineselongsword.com.

${ }^{9}$ A nice similarity to German fencing terminology is the use of the Chinese word dao (刀) for the one handed sabre. The word translates literally as "knife", denoting any single-edged blade - like in the case of the German "Messer", the categories of weapon and tool are blurred.

10 See the blog entry "Interesting parallels between Chao Xian Shi Fa (朝鮮勢法) and European swordsmanship" for a compilation of such seemingly similar positions for the two-handed sword. http://greatmingmilitary.blogspot.com/2016/01/interesting-parallels-between-chao-xian.html, accessed 27.09.2016. 
- Cultural surrounding: Both the societies of pre-modern Europe and China were highly organized, and socially stratified. For both, warfare, small-scale violence, and interpersonal combat was a reality, and political power was tied to military force. On the other hand, at least certain social elites of both cultural spheres were literate, and had developed a learned book culture that understood the written word as a primary means for the transmission of knowledge, while at the same time text production could be a marker of social status

- The medium of the fight book: Obviously, the foremost reason to compare European and Chinese fight books are the books themselves, and their - at least on the first glance - striking similarity. In both cultures, a combination of text and image was used to fixate techniques of close quarter combat for the reader. The detailed and accurate depiction of body postures, and the use of a specialized technical vocabulary are the fundamental characteristics in European as well as Chinese fight books. Some secondary phenomena, like the use of rhymed formula in text composition, can also be found in both cultures.

Of course, one might always argue that China is not Europe - and that any comparison of products of the two cultural spheres inevitably stands on shaky ground. And yet, deciding what not to compare is just as arbitrary as the opposite. Being too critical before we even begin comparing might prevent us from gaining valuable insights. After all, the study of the European fight books is also strongly dependent from the pre-assumption that the Western sources do belong to one single category. A notion that might be even stronger in a time when the first contact made with the fight books is usually via the computer screen. If one puts the physical objects themselves next to each other, the impression might change - seeing (as a very obvious example) an Egenolff and a Thibault side by side, one could start to ponder the question if they represent the same kind of medium at all (see Fig. 3). Rightfully, Karin Verelst pointed out to the "sheer number, variety and heterogeneity of the sources concerned", ${ }^{11}$ referring to the European material only.

11 Verelst, Introduction, p. 9. 


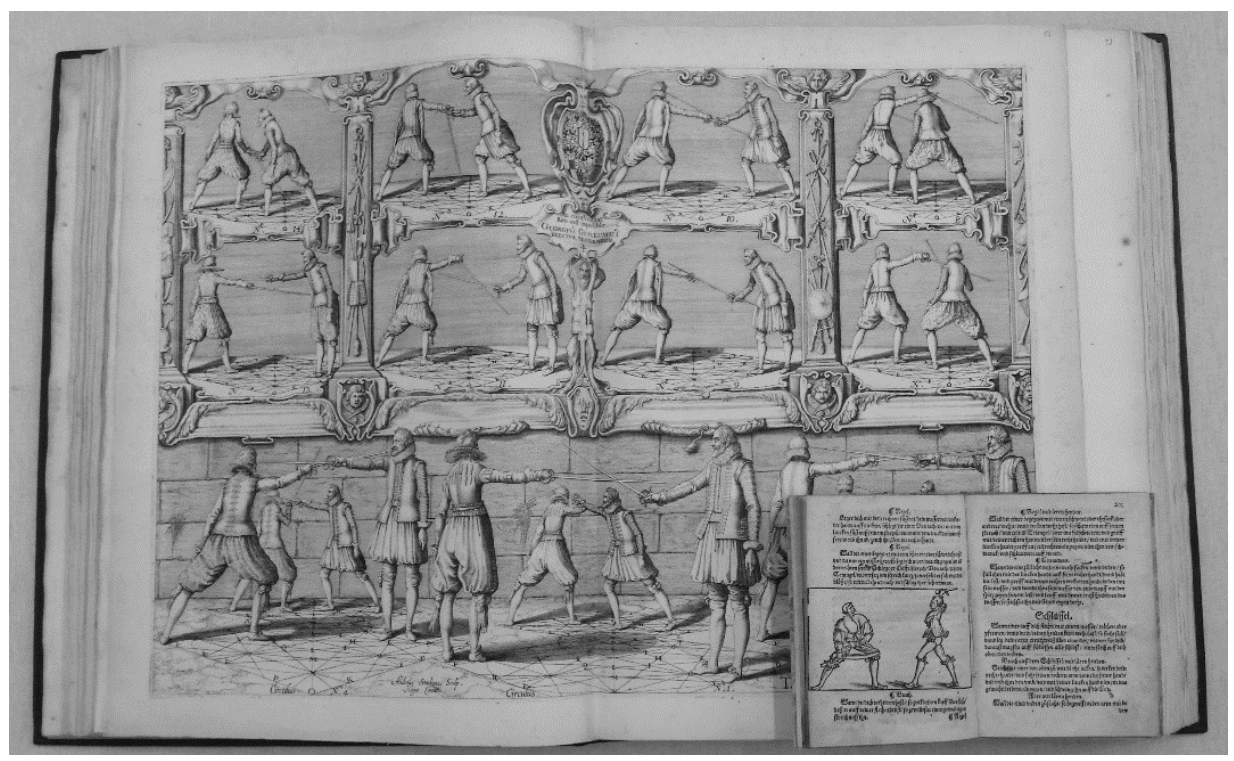

Figure 3: Anonymous, Fechtbuch, 1558; size (opened): $27 \mathrm{~cm} \times 18 \mathrm{~cm}, 86$ pages, and Thibault, Academie, 1630; size (opened): $84 \mathrm{~cm} \times 54,5 \mathrm{~cm}, 423$ pages. Photo by the author.

"The past is a foreign country: they do things differently there", as is well known. Imperial China was foreign to the European fight book authors, but so was the past of their earlier compatriots. What we are dealing with is a continuum of foreignness, not a binary.

To sum up all these preliminary considerations: The following pages will attempt to put Chinese and European fight books into perspective, and to highlight some of the aspects regarding which they can be compared. Before that, a short overview over both the European and the Chinese fight book tradition shall be given.

\section{II.1. The European fight book tradition}

Assuming that most of the readers of the APD will be familiar with the European sources, a quote from latest research shall for now suffice to describe them. "Figh book" shall be understood here as

terminus technicus used to indicate a vast and heterogeneous collection of manuscripts and printed books, destined to transmit on paper (or parchment) in a systematised way a highly complex system of gestures or bodily actions, often, but not always, involving the use of weapons of different sorts. The system represents a body of experience-based oral knowledge concerning all aspects of individual combat, both 
armed and unarmed, and taking place in different socio-cultural contexts and material situations [...] The group comprises fencing manuals in the classical sense, but also works on unarmed combat, mounted combat, combat in armour, combat against multiple opponents, and combinations of those. Situations envisaged comprise primarily forms of normed or ritualised civilian combat like judicial duels, duels of honour or competition, as well as self-defense. The fact that military usage, although not absent, is rather marginal may come in as a surprise, but it is clear from the material that focuses almost exclusively on combat in pairs and in circumstances subject to rules and normed behaviour.

The period from which the presently known treatises stem ranges from the early $14^{\text {th }}$ c., well into the $17^{\text {th }}$ c. [...] Sources moreover can be found in many different cultural and linguistic realms. In their material appearance, the works confront us with an equally resplendent variety of codicological and iconographical approaches, clearly connected to the didactical and and rhetorical means, aims and audiences pursued and addressed in every single one of them. [...] Fight books could be destined for either a very restricted audience or, in contrast, for one as wide as possible, and all nuances between these two extremes. ${ }^{12}$

\section{II.2. The Chinese fight book tradition}

China developed a "serious historical study"13 of its own martial arts tradition in the first half of the $20^{\text {th }}$ century:

Men like Tang Hao (1887-1959) pioneered the field of martial arts history. In the attempt to figure out where the martial arts fit into modern Chinese society, it was natural that someone would try to define martial arts. Tang successfully cut through the veil of myths, folklore, and advertising to begin tracking martial arts practice back to specific times, places, and individuals. ${ }^{14}$

Unfortunately for the scholar unable to read Chinese, very little of the material these pioneers provided has been translated into Western languages, and Western discourse on Chinese martial arts remained to a large degree under the influence of the mythic

\footnotetext{
12 Ibid., pp. 9-11.

${ }^{13}$ Lorge, Chinese Martial Arts, p. 219.

14 Ibid. For further information on the pioneers of Chinese martial arts studies, see: Kennedy, Training Manuals, pp. 38-64.
} 
narrations these arts told (and still tell) about themselves. ${ }^{15}$ Although of great importance for several perspectives of martial arts studies, ${ }^{16}$ such mythic narrations are no great help where the history of martial arts are concerned. Often, the Western researcher has to rely on a rather limited number of scholarly works on a given topic. ${ }^{17}$ The most important title for the questions at hand is surely Chinese Martial Arts Training Manuals: A Historical Survey by Brian Kennedy and Elizabeth Guo. ${ }^{18}$ The two authors give an overview over the field, from pre-modern times until well into the $20^{\text {th }}$ century. Unfortunately, helpful as it is, the title does not always meet scholarly standards, and sometimes leaves the reader confused by presentation of the material. Although the following discussion relies heavily on Kennedy and Guo, I have therefore tried to check back their information with the works of other authors, namely Lorge, Ranné, Shahar, and Wile. ${ }^{19}$ As a very useful online resource, the website Chinese Longsword has to be mentioned. ${ }^{20}$

The first known Chinese text that could be classified among the fight books seems to have been the Six Chapters on Hand Fighting. It is mentioned, among other books concerning military matters, in the Yiwens $h i$ ("Treatise on Literature"), the bibliographical section of the encyclopaedic Han Shu. To the disappointment of the martial arts historian, no copy of the Six Chapters survived, and Ban Gu (32-92 AD), the compiler of the Yiwenzhi, did not describe their contents. ${ }^{21}$

The first surviving Chinese fight books, however, come from a much later time. Without illustrations, but with detailed information on martial arts training, is the $W u$ Bian ("Book on Martial Techniques") compiled by Tang Shunzhi (1507-1560). It explains twelve different martial arts, and the part on empty hands fighting contains a theory of shi (postures), training methods, and a partial list of sequences from Wen family boxing. The $W u$ Bian's teaching of spear techniques was later integrated in the Jixiao Xinshu ("New Treatise on Military Effectiveness") of General Qi Jiguang from 1561, the first known

15 Stanley E. Henning was one of the first Westerners who vigorously attacked the naïve faith in the historicity of such myths: "This article will [...] hopefully extract them [the Chinese martial arts] from the realm of myth and pave the way for placing them in the realm of reputable historical research.” Henning, 'Historical Perspective', p. 173.

16 Wetzler, 'Myths', p. 10.

${ }^{17}$ For a general introduction into Chinese martial arts history, see: Lorge, Chinese Martial Arts. An amazing, up-to-date resource for modern Chinese martial arts studies is Ben Judkin's internet blog Kung Fu Tea: Martial Arts History, Wing Chun and Chinese martial studies, https://chinesemartialstudies.com/.

18 Kennedy, Training Manuals.

${ }^{19}$ Lorge, Chinese Martial Arts. Ranné, Wiege des Taijiquan. Shahar, Shaolin Monastery. Wile, T'ai-chi Classics.

${ }^{20}$ Chinese Longsword (http://www.chineselongsword.com/), accessed 27.09.2016

${ }^{21}$ Kennedy, Training Manuals, p. 99. 
Chinese fight book to combine text and illustrations. ${ }^{22}$ Many other titles followed, and together created a whole genre. Kennedy and Guo divide the history of this genre into five periods:

1. Legendary period;

2. Early woodblock print period;

3. Hand copies period;

4. Republican period;

5. Modern period. ${ }^{23}$

The "legendary period" refers to texts that do exist only in the origin myths ${ }^{24}$ of some Chinese styles. An example is the scroll with martial arts techniques allegedly discovered by the re-inventor of Xingyi boxing in an old temple. ${ }^{25}$ Such legendary texts shall not be discussed here. It is tempting, however, to contrast this thinking to the attitudes of the modern HEMA community, where sometimes a certain "internal power" seems to be attributed to the fight books, and their transcriptions.

Also, "republican" and "modern period" will not be taken into consideration here. Books of this period are testimonials to the shape and development of Chinese martial arts of the $20^{\text {th }}$ century, and as such extremely important for martial arts studies. But they are products of modernity, influenced by China's (military and ideological) conflicts with the Western powers; and they rely to a large degree on photographic representation of martial arts techniques, which changes the circumstances of production and the arrangement of information significantly. This should not mean that books of these two periods could not also be compared with earlier material, on the contrary. But the restricted space for this article suggests to draw a line somewhere, and it seems reasonable to draw it here. In the following, I will mainly concentrate on the early woodblock prints, with some further examples from the "hand copies period". It must be noted, though, that woodblock prints and hand copies are, of course, not mutually exclusive chronologically, but can and do overlap: "When we speak of periods [...] we mean it in a mixed sense of time and type."26 As said above, the Jixiao Xinshu holds the place as the oldest surviving fight book of China that combines text and image. It was written in a strictly military context, which is not the

${ }^{22}$ I am utmost thankful to Bok Kyu Choi for his information on the $W u$ Bian and the Jixiao Xinshu, and his input to this article.

23 Ibid., pp. 96-113.

${ }^{24}$ Wetzler, 'Myths', pp. 1-3.

${ }^{25}$ Kennedy, Training Manuals, pp. 96-97.

${ }^{26}$ Kennedy, Training Manuals, p. 96. 
exception for the fight books of the woodblock period. They were often written by and for soldiers, and accordingly to the needs of military training. General Qi Jiguang, for example, explained in his book that he included empty hands methods not for their usefulness in actual combat, but as means of physical and mental conditioning, and even dropped them from the later edition of his manual. ${ }^{27}$

Important authors of this period are:

- General Tang Shunzhi (1507-1560): Wu Bian (“Book on Martial Techniques”); includes descriptions of twelve different martial arts

- General Qi Jiguang (1528-1588): Jixiao Xinshu ("New Treatise on Military Effectiveness"); ca. 1561; five chapters on martial arts techniques, with weapons and empty handed

- General Yu Dayou (1503-1579): Zhengqi Tang Ji ("Compilation of Vital Energy"), therein Jian Jing ("Sword Classic")

- Cheng Zong You (1561-?): “On Martial Arts during the Fallow Season", published 1621, includes Dan Dao Fa Xuan ("Long Sabre Manual"), Chang Qiang Fa Xuan ("Spear Manual"), Shao-Lin Gun-Fa Can-Zong ("Shaolin Staff Methods") and crossbow material

- Cheng Zi Yi (nephew of Cheng Zong You): manuals on long shaft axe, the halberd, the big/crescent sabre, the 'whip',

- Mao Yuanyi (1594-1640): Wu Bei Zhi ('Military Preparation Manual'); longest Chinese book on military affairs, chapters on armed and unarmed martial arts

- Wu Shu (1611-1695): Shou Bi Lu ("Records of Arms"); four parts: two on spear, one on sabre, one on other weapons

- Cheng Zhen Ru (early Qing Dynasty): "Art of E'mei Spear"

- Shaolin Monk Xuan Ji (?), various compilers: "Fist Method"; collected around mid-17th century, printed in 1784; unarmed combat

\section{II.3. Areas of comparison}

Our comparison of Chinese and European fight books shall now move from the immediately visible to the more abstract characteristics of the books. Of course, these characteristics will often be interconnected. ${ }^{28}$ The list presented here is in no way supposed to be a definite one. Other areas can and will be found, once research begins.

\footnotetext{
27 Lorge, Chinese Martial Arts, p. 177.

28 Beyond the areas mentioned here, I have proposed an open list of "classes of phenomena" in the martial arts. The fight books can be questioned for their depiction of all these phenomena, too. See Wetzler, 'Martial Arts Studies', pp. 26 -28.
} 
Materiality: Even though it may seem trivial - the fight books are constituted in the first place by their material existence. This materiality has to be taken into account, and also the circumstances of book production. What can size, material, handwriting/printing technique, use-marks and preservation state reveal about the intended function and actual use of book? Do they give us hints if we are dealing with notes for personal purposes, lavishly illustrated "advertisement material", or truly didactic literature? Are layout and content optimal results of the authors intentions, or are they dependent from economic and technical necessities?

Depiction of technique: Like European fight books, the Chinese texts strive to divide the movement repertoire of a given martial art into small, intelligible and digestible parts. In other words, they identify and transmit either individual "techniques", or certain principles of movement. In the European tradition this will often happen by pitting two fencers against each other in the illustration, and explaining the movements of the one and the other as dialogue of question and answer. In the Chinese books, another strategy seems prevalent: The images usually do not show the "Hauptfunktionsphase"29 of a technique in application, but instead depict a single figure in starting position, during a technique, or at its end. The associated text describes the technique in question. Especially the depiction of starting positions, in which body and weapon are readied in a certain way, remind us of the guards of the European fight books, while the texts correspond to their technical explanations. Furthermore, it is noteworthy how the books try to convey transitions from one position into another to their readers. While the European tradition introduced, e.g., clarifying "footprints" into its images (beginning with the fight book of Sainct Didier, 1573, see Fig. 4), some Chinese examples feature complex "movement chains" that connect and explain such transitions (Fig. 5).

${ }^{29}$ Compare Welle, Höbischheit, p. 136. 


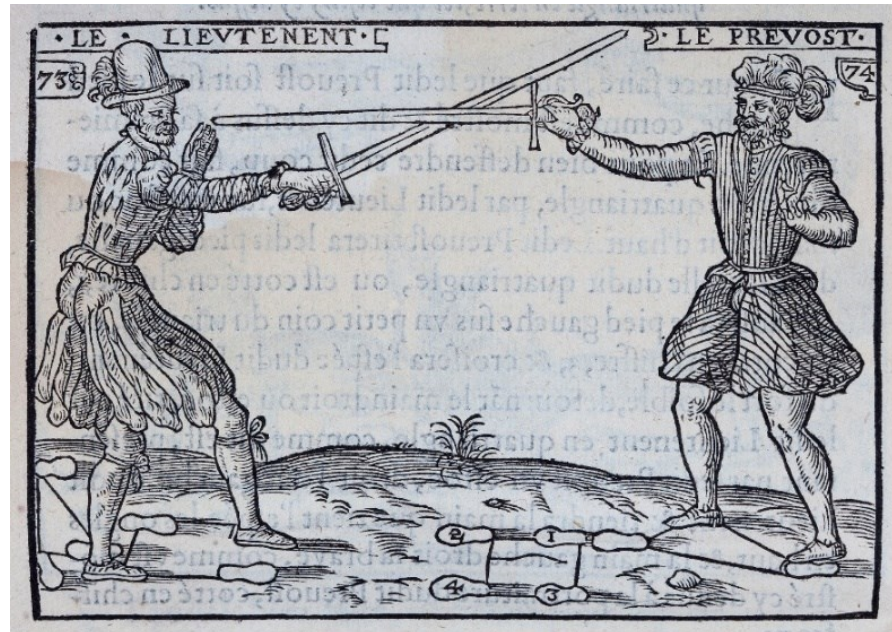

Figure 4: Footwork patterns. Sainct Didier, Traicte, 1573, fol. 58v. Photo by Lutz Hoffmeister, Deutsches Klingenmuseum.

\section{Form}

A more pictorial descroptiomn of the Chinese Long-saber form.

The stances are circled, and linked by the words describing how you would transit from one stance to the other.

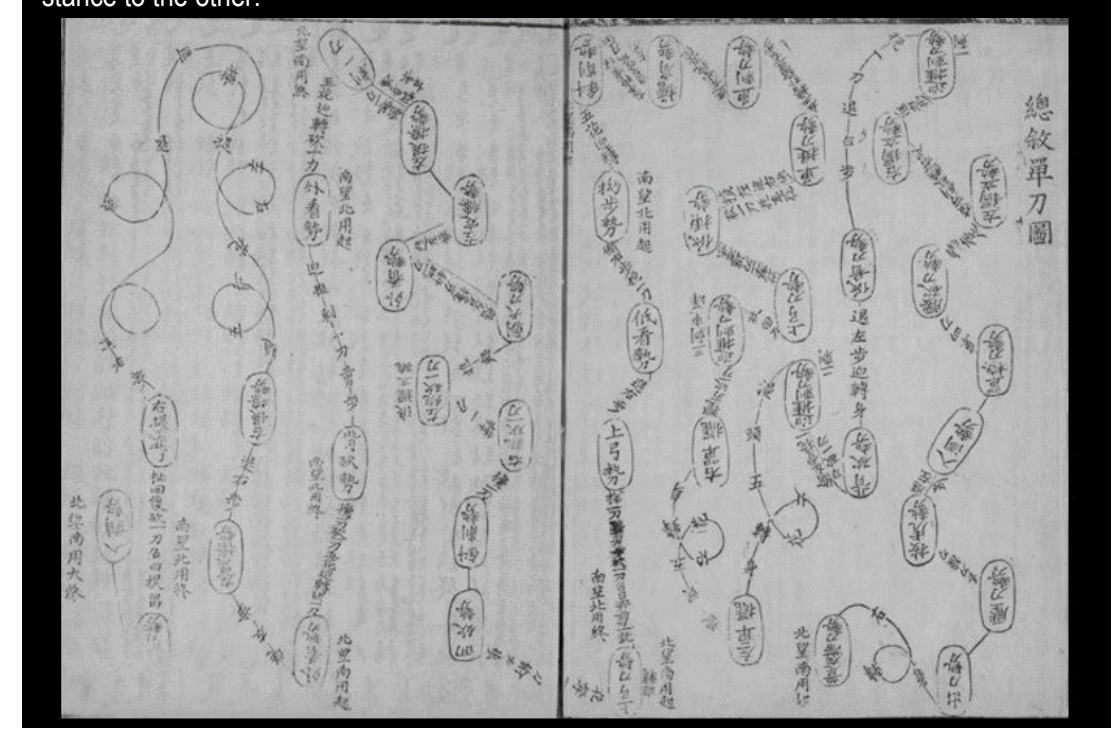

Figure 5: Pattern of a long sabre form. Cheng Zong You, Dan Dao Fa Xuan, 1621, ed. and comm. by Jack Chen, p. 17. Reproduced with permission of Jack Chen, www.chineselongsword.com. 
Textuality: In both cultural spheres, a specific terminology had developed to denote key features of the depicted martial arts. This starts in Europe with the oldest surviving fight book, the I.33, interspersing the Latin text with Middle High German termini technici. In China, too, we find such terminology from the oldest material on, when Qi Jiguang uses terms like the "seven star strike" or the "golden rooster". 30 The communicative strategies behind these terminologies would be interesting to research and compare: What parts of the martial arts were identified as singular and thus nameable entities? Do the terms ascribed imply similar ideas that were connected to bodily movement? In how far was the terminology embedded in its linguistic context? 31

Connected is furthermore the question in which ways texts are formed, and which communicative strategies stand behind these forms. Qi Jiguang, for example, put his text in verses, thus following traditional form ${ }^{32}$ and putting his work in the context of Chinese literature - but probably also to make the technical pieces easier to memorize, as it seems also the case with several European fight books. Later Chinese fight books sometimes follow quite the opposite strategy:

The oldest existing hand-copied manuals date from [...] about 1730. [...] They were largely useless unless one had already trained in that school, as the texts tended to be made up of shorthand notes, mnemonic rhymes, and esoteric philosophy. These hand-copied texts were intended exclusively for students of that lineage. ${ }^{33}$

Weaponry: As mentioned before, European and Chinese weaponry as depicted in the respective fight books (and demonstrated by surviving examples) was different, but not entirely alien. In both traditions, a great variety of weapons and also unarmed techniques come into play. However, where the European texts rather portray the sword as the heart of the martial arts, the Chinese books of the early woodblock print period lay an emphasize on pole weapons, which seems a result of their military context:

Spear fighting was a critical martial art for the military [...] Soldiers appear to have been given a much more thorough training in spear fighting than was stricly necessary for fighting in formation. They were fully trained in individual combat with the spear [...] Manual writers were at pains to survey and discuss the available styles of fighting [...] The

\footnotetext{
30 Qi Jiguang, Quanjing, p. 59. See there for a complete list of the technical terms for unarmed fighting in the Jixiao Xinshu and a comparison with the terminology of modern taijiquan, pp. 59-60.

31 Concerning linguistic aspects of the European tradition, see Bauer, Teaching how to fight.

32 Qi Jiguang, Quanjing, p. 19.

${ }^{33}$ Kennedy, Training Manuals, p. 101.
} 
spear was a ubiquitous weapon in Ming China, more important on the battlefield than the sword $[\ldots] \cdot{ }^{34}$

Interpretation of the depicted movements is always a delicate work; however, it is highly interesting to compare if similar armament coincides with similar tactical assessment and similar body techniques. Sometimes, the parallels thus obtained are striking - for example about the attitude towards the value of unarmed training:

From the 3227a: "And know that all courtliness [here: courtly arts/artes mechanicae] comes from wrestling. And all fencing has its cause and foundation in wrestling." 35

And with the words of Qi Jiguang:

The fist methods do not seem to concern themselves with the arts of great warfare; nevertheless, to move the hands and feet actively and to work habitually the limbs and body constitutes the gateway to beginning study and entering the art. Therefore I have reserved it for the end so as to complete the whole school. ${ }^{36}$

Martial arts context: The authors of fight books both in China and in Europe were not the sole masters of combat in a world otherwise void of martial arts. On the contrary. They were protagonists in a highly dynamic polysystem of martial arts styles, ${ }^{37}$ and they were aware of that fact. Fiore dei Liberi, for example, "boasts in the Pisani-Dossi manuscript that he studied with a master named Johannes 'called Suveno,' that is, from Swabia in present-day Germany," 38 thus demonstrating his understanding of the diversity of his contemporary martial arts culture. The codex 3227 a famously speaks of inefficient and corrupted methods of fencing, in contrast to Master Liechtenauer's - that is, the proper - teaching: "And Liechtenauer names only five strikes with their techniques, which are useful for serious ${ }^{39}$ fighting. And he teaches to apply them in the most simple and

${ }^{34}$ Lorge, Chinese Martial Arts, pp. 180-181.

35 Und wisse das alle hobischeit kompt von deme ringen. Und alle fechten komen ursachlich und gruntlich vom ringen. $3227 \mathrm{a}, 86 \mathrm{r}$.

${ }^{36}$ Qi Jiguang, Quanjing, p. 33. Note that also in 3227a, the grappling section is the last among the martial arts parts. However, the compilation of the codex is a complex matter, and should warn against rash conclusions. See Burkart, 'Autograph', pp. 460-466.

37 More on the possibility to use Itamar Zohar's polysystem theory on martial arts as cultural phenomena in Wetzler, 'Martial Arts Studies', 28-30.

38 Mondschein, Knightly Art, p. 11.

39 In the context, "ernstem" (earnest, serious) would make more sense than "erstem" (first); maybe a misspelling by the author. I thank Eric Burkart for helping out with his personal copy of the $3227 a$. 
direct manner according to the true art, to the nearest and most direct aim that presents itself. And he strips away all false jugglery and newly invented strikes of the impostors, even though they are founded in his art." 40

The anonymous author thus stratifies the martial arts landscape not only geographically, like Fiore, but also in terms of the quality of combat skills.

Both is also done by Chinese authors. Qi Jiguang's discussion of contemporary hand combat systems gives a fascinating impression of the martial arts world that surrounded him:

Looking at Master Wen in the present day, we have the 72 moving fist methods, the 36 combining and locking techniques, the 24 counter-spy techniques, the 8 flash flips, and the 12 short strikes. These are the best of the lot. As for Lu Hong's 8 blows, while they are firm, they do not measure up to Min Zhang's short strike. The leg techniques of Shangdong's Li Bantian, Eagle Claw Wang's grappling methods, Thousand Stumble Zhang's stumbling techniques, Zhang Bojing's strikes, the Shaolin monastery stick fighting art, together with the Green Field cudgel methods, all stand as equals. Mr. Yang's spear arts together with the open hand, fist, and quarterstaff skills, are all famous to the present day. Although each one has its own specific proficiency, still as they are handed down, the traditions are incomplete, some missing the lower part, some missing the upper. ${ }^{41}$

Indeed, as Lorge points out:

Most of the authors were also concerned with what they called 'Flowery Boxing' [...], ineffective and overly elaborate styles that only looked nice. Indeed, one of the central issues of the discussion of boxing styles was effectiveness. There was a constant comparison between styles, or anecdotes recounting how someone practiced an ineffective or flawed style. ${ }^{42}$

\footnotetext{
40 Do nennet lichtnawer nir fimff hewe mit andern stocken, dy do nitcze seyn çu erstem vechten. Und leret dy noch rechter kunst slecht und gerade dar brengen, noch dem aller nebesten und schiresten als is nif dar komen mag. Und lest alles trummelwerk und newfunden bewe underwegen von den leichmeistere, dy doch gruntlich aus syner kunst dar komen. 3227a, 14v-15r. I thank Matthias Johannes Bauer for his input on the translation of the 3227 a quotes.

${ }^{41}$ Qi Jiguang, Quanjing, p. 35.

${ }^{42}$ Lorge, Chinese Martial Arts, p. 177.
} 
In a wider perspective, the social context of the martial arts depicted in the books has to be taken into consideration. If the books are, e.g., works from a literate, urban upper class (as is it often the case in Europe), or are rather to be seen as military resources (like in China), in how far did these contexts influence not only shape and content, but also distribution and acceptance?

\section{CONCLUSION}

Considering the preliminary thoughts and possible areas of comparison listed above, one feels inclined to assume that further research into a comparison of the European and the Chinese fight book tradition would indeed be a worthwhile undertaking. In this way, one important field of HEMA studies would be incorporated into the larger field of martial arts studies. Martial arts studies, on the other hand, would surely benefit from the theoretical and methodological reflections the research on the European sources has produced so far.

The descriptions of the areas of comparison were, of course, only rough sketches. For a thorough (and convincing) approach, each fight book would first have to be understood as an own entity, and within its respective socio-historical context; then, the fight books of a given tradition would have to be compared and put into context with each other; and finally, cross-cultural (or cross-historical) comparisons can be attempted. Of course, such an approach is not restricted to the books of the historical European and Chinese martial arts. Other societies have produced similar kinds of literature, like the swordsmanship scrolls of Japan, the famous Muyedobotongii of late $18^{\text {th }} \mathrm{c}$. Korea, or the semi-legendary Nibang-Nama of India (Fig. 6). ${ }^{43}$

\footnotetext{
43 "The most important manuscript, exclusively devoted to the sword, is Nihang-Nama (the Book of the Sword) of Deccan. A few inscribed and illustrated leaves of this manuscript, datable to the 18th century A.D., are preserved in the National Museum, New Delhi. Holding the sword in upright hand and its brandishing, attacking the enemy, defending oneself from the enemy strokes, standing poses, modes of wielding the sword, etc., have very minutely been illustrated." Pant, Indian Arms, p. 19.
} 


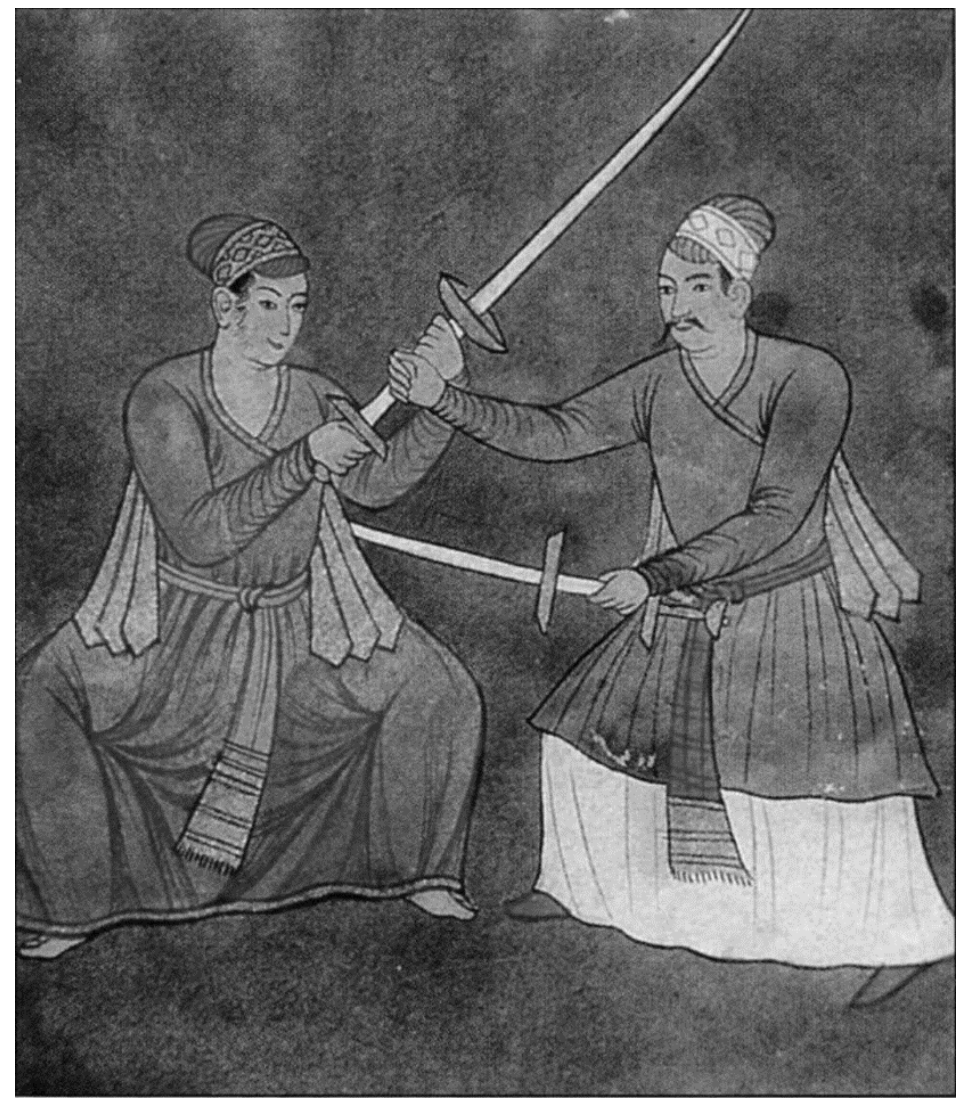

Figure 6: Fencing with the mel puttah bemoh, the Indian two-handed rapier. Anonymous,

Nihang-Nama, $18^{\text {th }}$ century (New Delhi, National Museum). Image reprinted from bttps:// commons.wikimedia.org/wiki/File:Nihang_nama_Mel_Puttah_Bemoh.jpg, accessed 27.09.2016.

Furthermore, research must not necessarily be contained to forgone centuries. As Eric Burkart has recently shown, a Talhoffer manuscript from the $15^{\text {th }}$ and a krav maga manual from the $21^{\text {st }}$ century can indeed be put under the same lense, and with good results. ${ }^{44}$

${ }^{44}$ Burkart, 'Kampf anhalten'. 
To provide time and room for the cross-cultural and cross-historical comparison of fight books, Deutsches Klingenmuseum Solingen (German Blade Museum) will host an international academic conference on the topic in the autumn of 2017.45

\section{BIBLIOGRAPHY}

\section{IV.1. Primary sources}

Anonymous, I.33, ca. 1320 (Leeds, The Royal Armouries, MS I.33).

Anonymous, 3227 a, around 1389 (Nuremberg, Germanisches Nationalmuseum, Hs. 3227a)

Anonymous, Fechtbuch. Die Ritterliche / Mannliche Kunst und Handarbeyt Fechtens / und Kempfens [...], Frankfurt a.M., Christian Egenolff (heirs), 1558 (4th ed.).

Anonymous, Nibang-Nama, unknown date (New Delhi, National Museum).

Cheng Zi Yi, Long Shaft Axe, unknown date, ed. and comm. by Jack Chen, http://www.chineselongsword.com/axe, accessed 27.09.2016.

Cheng Zong You, Dan Dao Fa Xuan. 400 years old ancient Chinese Long-Saber manual, ed. and transl. by Jack Chen, http://www.chineselongsword.com/longsaber, accessed 27.09.2016.

Fiore dei Liberi, Il Fior di Battaglia, ca. 1410 (Los Angeles, J. Paul Getty Museum, MS Ludwig XV 13).

Girard Thibault d'Anvers, Académie de l'epée, ou se démontrent par reigles mathématique, sur le fondement d'un cercle mysterieux, la theorie et pratique des vrais et jusqu' a present incognus secrets $d u$

maniement des armes, a pied et a cheval, Leiden, Elzevier, 1630.

Henry de Sainct Didier, Traicte contenant les secrets du premier livre sur l'espee seule, Paris, Jean Mettayer and Matthurin Challenge, 1573.

Qi Jiguang, An English Translation of General Qi Jiguang's "Quanjing Jieyao Pian” (Chapter on the Fist Canon and the Essentials of Nimbleness) from the Jixiao Xinshu (New Treatise on Disciplined Service), transl. by Clifford Michael Gyves (Master thesis, Department of East Asian Studies, University of Arizone, 1993), http://www.dtic.mil/dtic/tr/fulltext/u2/a268051.pdf, accessed 27.09.2016.

45 The museum owns itself a precious collection of European fight books, the oldest dating to the mid-16 $6^{\text {th }}$ century. Further information on the conference will appear on the museum's website www.klingenmuseum.de, and will be distributed via the usual channels. 


\section{IV.2. Secondary sources}

Bauer, Matthias Johannes, 'Teaching How to Fight with Encrypted Words. Linguistic Aspects of German Fencing and Wrestling Treatises of the Middle Ages and Early Modern Times', in Late Medieval and Early Modern Fight Books. Transmission and Tradition of Martial Arts in Europe (14th-17th Centuries), ed. by Daniel Jaquet et al., History of Warfare 112 (Leiden: Brill, 2016), pp. 47-61.

Bowman, Paul, Martial Arts Studies. Disrupting Disciplinary Boundaries (London: Rowman \& Littlefield, 2015).

Burkart, Eric, 'The Autograph of an Erudite Martial Artist. A Close Reading of Nuremberg, Germanisches Nationalmuseum, Hs. 3227a', in Late Medieval and Early Modern Fight Books. Transmission and Tradition of Martial Arts in Europe (14th-17th Centuries), ed. by Daniel Jaquet et al., History of Warfare 112 (Leiden: Brill, 2016), pp. 451-480.

Burkart, Eric, 'Den Kampf anhalten. Bildliche Bewegungsdidaktiken in moderner Ratgeberliteratur und in europäischen Handschriften des 14. und 15. Jahrhunderts'. In Die Welt anhalten. Von Bildern, Fotografie und Wissenschaft, ed. by Günter Burkart and Nikolaus Meyer (Weinheim: Beltz, 2016), [in print].

Freiberger, Oliver, (2012), 'Der Vergleich als Methode und konstitutiver Ansatz der Religionswissenschaft', in Religionen erforschen. Kulturwissenschaftliche Methoden in der Religionswissenschaft, ed. by Stefan Kurth and Karsten Lehmann (Wiesbaden: VS Verlag für Sozialwissenschaften, 2012), pp. 199-218.

Henning, Stanley E., 'The Chinese Martial Arts in historical perspective'. Military Affairs, 45/4 (1981), pp. 173-179.

Jaquet, Daniel et al., eds., Late Medieval and Early Modern Fight Books. Transmission and Tradition of Martial Arts in Europe (14th-17th Centuries), History of Warfare 112 (Leiden: Brill, 2016).

Kennedy, Brian, and Elizabeth Guo, Chinese Martial Arts Training Manuals. A Historical Survey (Berkeley CA, Blue Snake Books, 2005).

Kuhn, Peter et al., eds., Kampfkunst und Kampfsport in Forschung und Lehre 2011. 1. Internationales Syposium "Kampfkeunst und Kampfsport" vom 6.-7. April 2011 in Bayreuth, Schriften der Deutschen Vereinigung für Sportwissenschaft 220 (Hamburg: Feldhaus Edition Czwalina, 2011).

Lorge, Peter A., Chinese Martial Arts. From antiquity to the twenty-first century (Cambridge et al., Cambridge Univ. Press, 2012).

Mondschein, Ken, The Knightly Art of Battle (Los Angeles CA: Getty Publications, 2011).

Pant, Gayatri Nath, Indian Arms and Armour. Volume II (Swords and Daggers) (New Delhi: Army Educational Stores, 1980). 
Ranné, Nabil, Die Wiege des Taijiquan. Der soziokulturelle Kontext der chinesischen Kampfkunsttheorie mitsamt einer Analyse der ältesten Bewegungsformen des Taijiquan (Berlin: Logos, 2011).

Shahar, Meir, The Shaolin Monastery. History, Religion, and the Chinese Martial Arts (Honolulu HI: University of Hawai'i Press, 2008).

Verelst, Karin (with Timothy Dawson and Daniel Jaquet), 'Introduction', in Late Medieval and Early Modern Fight Books. Transmission and Tradition of Martial Arts in Europe (14th-17th Centuries), ed. by Daniel Jaquet et al., History of Warfare 112 (Leiden: Brill, 2016), pp. 7-27.

Welle, Rainer, “... und wisse das alle höbischeit kompt von deme ringen”. Der Ringkampf als adelige Kunst im 15. und 16. Jahrhundert; eine sozialhistorische und bewegungsbiographische Interpretation aufgrund der handschriftlichen und gedruckten Ringlehren des Spätmittelalters, Forum Sozialgeschichte 4 (Pfaffenweiler: Centaurus, 1993).

Wetzler, Sixt, 'Myths of the Martial Arts', JOMEC Journal, 5 (2014), https://publications.cardiffuniversitypress.org/index.php/JOMEC/article/view/332 /339, accessed 27.09.2016.

Wetzler, Sixt, 'Martial Arts Studies as Kulturwissenschaft. A Possible Theoretical Framework', Martial Arts Studies Journal, 1 (2015), pp. 20-33, http://masjournal.org.uk/issue-1-autumn-2015, accessed 27.09.2016.

Wile, Douglas, Lost T'ai-chi Classics from the Late Ch'ing Dynasty (Albany NY: State University of New York Press, 1996).

\section{IV.3. Online resources}

Chinese Longsword, http:/ / www.chineselongsword.com, accessed 27.09.2016.

Homepage der dvs-Kommission "Kampfleunst und Kampfsport", http:/ / www.sportwissenschaft.de/index.php?id=kkk, accessed 27.09.2016.

'Interesting parallels between Chao Xian Shi Fa (朝鮮勢法) and European swordsmanship', http://greatmingmilitary.blogspot.com/2016/01/interestingparallels-between-chao-xian.html, accessed 27.09.2016.

Kung Fu Tea: Martial Arts History, Wing Chun and Chinese Martial Studies, https://chinesemartialstudies.com, accessed 27.09.2016.

The Martial Arts Studies Research Network, https://mastudiesrn.wordpress.com/conference-2, accessed 27.09.2016. 